EOSINOPHILIA IN BILHARZIA DISEASE AND DRACONTIASIS.

By ANDREW BALFOUR, M.D., B.Sc., M.R.C.P. EDIN., D. P.H. САMB.,

DIRECTOR, RESEABCH LABORATORIES, GORDON COLLEGE, KHARTOUM.

IN THE LANCET of Oct. 10th, 1903, p. 1009, there is an article by Captain S. R. Douglas, I.M.S., and Major F. W. Hardy, R.A.M.C., on 50 Cases of Bilharzia Disease in which they give an account of the results obtained by them in the differential leucocyte counts. Their very complete and interesting investigation was apparently instigated by Coles's observations ${ }^{1}$ on one case of bilharzia disease in which he found an increase of coarse-grained eosinophile leucocytes. His case was that of a young Englishman in whose blood he discovered 20 per cent. of these cells instead of the normal 7 per cent. (Hayem). With a view to confirming Coles's solitary observation I proceeded in my spare time to examine the blood of the few bilharzia cases I could obtain in Khartoum and Omdurman. Bilbarzia disease, so far as is known, does not occur in the Egyptian Sudan save amongst those who have acquired the infection in Egypt or elsewhere, and owing to this and other reasons I was only able to examine three cases. At the same time I thought it well to investigate the blood condition in dracontiasis. At the time I began to do so I believe no work had been accomplished on this subject, but while I was thus employed a paper ${ }^{2}$ appeared by Dudgeon and Child recording their results in one case of guinea-worm disease in an Englishman infected in India and resident in London. They found from 13.0 to 18.4 per cent. of coarse-grained eosinophiles present and suggest that in this respect dracontiasis may occupy a position midway between trichiniasis and infections with other internal parasites. I have notes on six cases of guineaworm disease and had intended collecting further statistics before publishing any account of them, but as I find my results confirm theirs in large measure $I$ think it well to place them on record, especially as some time must needs elapse before I can add materially to my number of cases.

Method.-In each instance I connted 500 leucocytes and in nearly every case made a double examination, one film being stained by Jenner's method and the other by the LeishmanRomanowsky. The counts were found to approximate very closely and that obtained in the better-stained film was taken as correct. In several instances also other confirmatory counts were made. In differentiating large mononuclears from lymphocytes I followed the plan adopted by Captain Leonard Rogers and classed every single unlobed nucleated corpuscle as large as, or larger than, a polymorphonuclear as a large mononuclear. Like Captain Delany, I preferred to place transitional forms under the heading polymorphonuclears, but $I$ see that Dudgeon and Child counted them as lymphocytes.

Table of results.-For convenience of reference I place the accepted normal percentages in the table (Table I.).

TABLE 1.-Cases of Bilharia Disease.

\begin{tabular}{|c|c|c|c|c|c|c|c|}
\hline \multirow[b]{2}{*}{ No. } & \multirow[b]{2}{*}{ Cases. } & \multirow[b]{2}{*}{ Remarks. } & \multicolumn{5}{|c|}{$\begin{array}{l}\text { Percentage of various } \\
\text { leucocytes. }\end{array}$} \\
\hline & & & 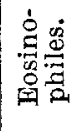 & 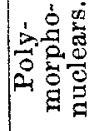 & 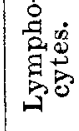 & 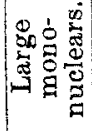 & 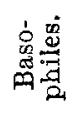 \\
\hline - & - & Normal. & $4-7$ & $70-75$ & $15-25$ & $6-8$ & 0.5 \\
\hline 1 & $\begin{array}{l}\text { Bilharzia of } \\
\text { the rectum. }\end{array}$ & $\begin{array}{l}\text { Egyptian soldier, } \\
\text { Omdurman. }\end{array}$ & $18 \cdot 0$ & $49 \cdot 0$ & $12 \cdot 6$ & $20 \cdot 4$ & - \\
\hline 2 & $\begin{array}{l}\text { Bilharzia of } \\
\text { the rectum. }\end{array}$ & $\begin{array}{l}\text { Egyptian soldier, } \\
\text { Omdurman. }\end{array}$ & $14 \cdot 0$ & $28 \cdot 6$ & $46 \cdot 4$ & $11 \cdot 0$ & 0.6 \\
\hline 3 & $\begin{array}{l}\text { Bilharzia of } \\
\text { the bladder. }\end{array}$ & $\begin{array}{l}\text { Egyptian soldier, } \\
\text { Omdurman. }\end{array}$ & $18 \cdot 4$ & $35 \cdot 8$ & $33 \cdot 6$ & $12 \cdot 2$ & 0.2 \\
\hline
\end{tabular}

It will be seen that there was a very decided increase of coarse-grained eosinophiles and though the number of cases is very small, too small to furnish any definite conclusions, it

1 Eosinophilia associated with Dracontiasis, Journal of Tropical Medicine, August 15th, 1903.

2 Diseases of the Blood, Coles. is interesting to observe that the average percentage works out at 16.8, while in Captain Douglas's and Major Hardy's 50 cases it was $16 \cdot 486$. As is mentioned by them there is also a proportional diminution in the percentage of the polymorphonuclears and curiously enough in the one case (No. 1) in which there is a marked increase of the large mononuclears there is a diminution of the lymphocytes, a point to which they also draw attention. In the remaining two cases there is an increase in the lymphocytes.

TABLE II.-Guinea.worm Cases.

\begin{tabular}{|c|c|c|c|c|c|c|c|}
\hline \multirow[b]{2}{*}{ No. } & \multirow[b]{2}{*}{ Case. } & \multirow[b]{2}{*}{ Remarks. } & \multicolumn{5}{|c|}{$\begin{array}{c}\text { Percentage of various } \\
\text { leucocytes. }\end{array}$} \\
\hline & & & 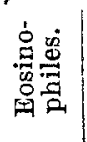 & 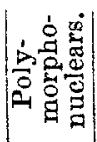 & 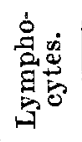 & 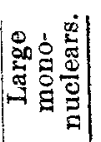 & 家离 \\
\hline 1 & $\begin{array}{l}\text { Greek, } \\
\text { Omdur- } \\
\text { man. }\end{array}$ & $\begin{array}{l}\text { In foot; much } \\
\text { induration. }\end{array}$ & 16.0 & $51 \cdot 0$ & 220 & $11 \cdot 0$ & - \\
\hline $1 a$ & $\begin{array}{l}\text { Same man, } \\
\text { Khartoum. }\end{array}$ & $\begin{array}{l}\text { Worm had been } \\
\text { wholly removed } \\
\text { two weeks before } \\
\text { this examination. }\end{array}$ & $15 \cdot 2$ & $42 \cdot 0$ & $27 \cdot 8$ & $15 \cdot 0$ & - \\
\hline 2 & $\begin{array}{c}\text { Egyptian } \\
\text { soldier, } \\
\text { Omdur- } \\
\text { man. }\end{array}$ & $\begin{array}{l}\text { Worm had been } \\
\text { wholly removed } \\
\text { two days before } \\
\text { examination. In- } \\
\text { duration was still } \\
\text { present in the foot. }\end{array}$ & $13 \cdot 4$ & $52 \cdot 8$ & $24 \cdot 4$ & $9 \cdot 4$ & - \\
\hline 3 & $\begin{array}{l}\text { Sudanese, } \\
\text { Khartoum. }\end{array}$ & $\begin{array}{l}\text { In foot : malaria, } \\
\text { but no rise of tem- } \\
\text { perature. }\end{array}$ & $34 \cdot 4$ & $36 \cdot 0$ & $13 \cdot 0$ & $16^{*} 6$ & - \\
\hline 4 & $\begin{array}{l}\text { Sudanese, } \\
\text { Khartoum. }\end{array}$ & $\begin{array}{l}\text { In foot ; malaria, } \\
\text { but no rise of tem- } \\
\text { perature. }\end{array}$ & 36.6 & 312 & $16 \cdot 4$ & $15 \cdot 4$ & 0.6 \\
\hline 5 & $\begin{array}{l}\text { Sudanese } \\
\text { soldier, } \\
\text { Khartoum. }\end{array}$ & $\begin{array}{l}\text { Double infection in } \\
\text { the arm. One } \\
\text { worm wholly re- } \\
\text { moved and a por- } \\
\text { tion of the other } \\
\text { three weeks before } \\
\text { exa min a t ion. } \\
\text { Probably malaria } \\
\text { present. }\end{array}$ & $6 \cdot 4$ & $38 \cdot 6$ & $28 \cdot 8$ & $26 \cdot 2$ & - \\
\hline 6 & $\begin{array}{c}\text { Sudanese } \\
\text { soldier, } \\
\text { Khartoum. }\end{array}$ & $\begin{array}{l}\text { In foot. Worm sup- } \\
\text { posed to have been } \\
\text { wholly removed, } \\
\text { but ulcer and in- } \\
\text { duration persisted. } \\
\text { Probably malaria. }\end{array}$ & $10 \cdot 8$ & $27 \cdot 8$ & $39 \cdot 6$ & $21 \cdot 8$ & 0.6 \\
\hline
\end{tabular}

There being, so far as I am aware, no other statistics with which to compare these results it is hardly worth while, with so few cases, to express the average percentage of eosinophiles or to discuss the relative numbers of the other forms of leucocyte. One point may, however, be raised. It is often a difficult matter to say if the whole of a guineaworm has been extracted. Might the percentage of eosinophiles be taken as a guide in such cases? I have not been able to follow out a case through all its stages but the results obtained seem rather suggestive, and if this be so the differential leucocyte count would have a practical and useful bearing. It will be seen that Case 3 and Case 4 gave a much higher percentage of coarse-grained eosinophiles than did the case in London. Further observations are indicated to decide the usual amount of eosinophiles which one may expect to find in dracontiasis. I am much indebted to Dr. J. B. Christopherson, Omdurman, and to Captain Cummins and Sadek Effendi, E.M.S., for kindly placing cases at my disposal in the military hospitals at Omdurman and Khartoum and in the Prison Hospital, Khartoum.

Khartoum.

\section{FEVER AND CONVULSIONS DUE TO ASCARIDES.}

\section{By ALBERT J. B. DUPREY, M.R.C.S. ENG.,} L.R.C.P. LOND.,

GOVERNMENT MEDICAL OFFICER, ST. LUCIA, WEST INDIES.

IT is interesting to find that "worm fever" and convulsions brought about by the presence of ascarides in the bowels are regarded as of rare occurrence. Grave symptoms and sometimes death from the harbouring of this parasite are, I venture to point out, of very frequent occurrence in 
the West Indies. Not only in children but even in adults toxæmic symptoms are not infrequently produced by the presence of these worms which, presumably from the large quantity present, sometimes die and putrefy in the bowels, giving rise to a condition of blood poisoning closely resembling the typhoid state. This condition of ascarides is extremely common in these parts in children varying between the ages of two and ten years. So, therefore, it is always wise in treating children to start by administering a worm powder even if the disease is recognised to be some other, for the presence of worms in the intestines contributes in no small degree to the great irritability to which patients of tender age are prone in all diseases. Round worms are not always easy to expel, for often the large number present are knotted together and not infrequently give rise to symptoms of slight obstruction ; at other times they are deeply embedded in mucus and no amount of santonin can get at them, so that the bowels are required to be freely active before the worms can be exposed and acted on by the vermifuge. In reading the letters published in THE $\mathrm{LANCET}^{1}$ concerning this matter I recalled to mind a case of ascarides once under my care, the notes of which I have by me.

The patient was a fairly well-nourished boy, aged eight years, who was admitted to a hospital on July 27th, 1897, for fever and "bad bowels." He was unconscious; his pupils were widely dilated and the conjunctival reflex was present. The eyes were protruded and deviated upwards and to the right; his teeth were clenched. His bowels were loose and the motions were extremely offensive. The surface of the body was cold. The breathing was free; no abnormal sounds could be detected in the lungs. The heart beats were rapid but otherwise normal. $\mathrm{He}$ had several fits and on admission there were noticed twitchings of the right side of the face, the right arm and leg, and the left side of the mouth. The abdomen was much swollen and tympanitic. The pulse was quick and regular. His tem. perature on admission was $102 \cdot 6^{\circ} \mathrm{F}$. A rectal tube was passed but no flatus came away; a calomel and santonin powder was given and turpentine stupes were applied to the abdomen. Later in the day he was given three grains of acetanilid. At $5.45 \mathrm{P}$.M. his temperature registered $100 \cdot 6^{\circ}$ and he rallied somewhat, the teeth being less clenched, while the abdominal walls seemed to have become softer, but he was still in a stuporous condition. At 8 P. M. he passed a foul motion and was perspiring freely. The bowels were then washed with weak Condy's fluidhalf an ounce in a quart of water. Ice was applied to the head. On the 28th there was some improvement since the previous day. The stupes were discontinued. The pulse and respirations were respectively 160 and 60 per minute, the skin was moist, and the temperature was $100 \cdot 4^{\circ}$. At 6 P.N. the temperature registered $101 \cdot 4^{\circ}$. The boy was still unconscious. There were constant movements of the head from left to right. The abdomen was less distended. One-eighth of a grain of calomel with sugar of milk was given every quarter of an hour for eight doses. On the 29th the patient was conscious in the morning and his temperature was normal but he was still very weak. The pulse was 140 per minute and regular. He passed a large and very offensive motion. Another large motion, black in colour, was passed about 11 P.M. The abdomen was flat and no tympanites was present. His aspect was dazed, the lips were dry, and there were sordes on the tongue and the teeth; the left thigh was flexed on the abdomen. He vomited and showed some restlessness. On the 30 th he had two dark loose motions and was very restless. On the 31 st he was rather poorly in the morning; there were sordes on his lips and teeth and his temperature was $103 \cdot 8^{\circ}$. He had occasional twitchings of the right half of the body at intervals of four or five minutes; there was spasm of the right arm, the right hand being brought constantly towards the right iliac fossa and vigorous scratching movements were made as if to remove some great irritation. He was given a mixture containing four grains of hydrochlorate of quinine, four grains of bromide of potassium, five minims of infusion of digitalis, and five minims of dilute phosphoric acid to one ounce of water every three hours. Stimulants were prohibited at this juncture. He never rallied but died at 1 A.M. on August 1st.

At the necropsy the body was found to be emaciated and there was neeling of the epidermis nver the abdomen. The

1 THe LANCE' Sept. 26th (p. 898), and Oct. 3rd (p. 979), 10th (p. 1052) and 17 th (p. 1119), 1903 . lungs were normal, as were all the abdominal organs. Round worms were found in the intestines two--were in the ileum, one was occupying the vermiform appendix like a gloved finger with the hind end projecting into the cæcum, and six. dead ones were in the large bowel. The mucous membrane of the bowels was in no wise diseased. On examining the brain the meninges were found to be normal, there was the usual quantity of cerebro-spinal fluid, and no gross pathological lesion could be discovered anywhere in the brain substance. The case was at first taken to be one of acute meningitis and it is interesting inasmuch as no explanation could be found to account for the symptoms with the exception of worms found in the bowels. The twitchings of the right arm and the scratching movements which were so marked were suggestive of great discomfort in the region of the iliac fossa, a symptom which, I think, is fully explained by the round worm found occupying the vermiform appendix where the irritation must have been very considerable. St. Lucia, West Indies.

\section{Clinital allotes:}

\section{MEDICAL, SURGICAL, OBSTETRICAL, AND} THERAPEUTICAL.

\section{DEFORMITY OF THE HEART IN THE MONGOLIAN IMBECILE.}

By Charles H. Fennelt, M.A., M.D. Oxon., M.R.C.P. LoND, ASSISTANT MEDICAL OFFICER, DARENTH ASYLUM.

IN a paper read before the Clinical Society of London in 1898 and published in vol. xxxii. of the Transactions Dr. Archibald Garrod described five cases of Mongolian imbecility in which evidence of congenital malformation of the heart was present. All the patients were under three years old and Dr. John Thomson's wide experience was quoted as not including a child of more advanced years showing cardiac deformity. The suggestion was made that Mongolian imbeciles thus affected probably died in very early years. I have therefore thought it of interest to record three cases, varying in age from nine to 27 years, met with in the detailed examination of 23 of these imbeciles at Darenth Asylum.

CASE 1.-Male, aged 27 years, a very definite specimen of the type. He is a low-grade imbecile, in good bealth, and not at all anæmic. The area of cardiac dulness extends one and a half tingers' breadth to the right of the sternum; on the left side it reaches the nipple line. A to-and-fro murmur is heard in the upper three intercostal spaces on each side of the sternum, but best in the second left space and better along the left sternal border than the right. There is no cyanosis or clubbing and the patient has had no syncopal attacks ; his heart works adequately and he is a useful ward helper.

CASE 2. - Female, aged nine years, a low-grade imbecile of well-marked Mongolian type. She is in fair health but subject to catarrb. T'he area of cardiac dulness extends one and a half fingers' breadth to the right of the sternum; its left limit is half a finger's breadth inside the nipple line. There is a diastolic bruit at the left base, replacing the pulmonary second sound and best heard in the second left intercostal space. No systolic bruit is audible. The child shows no cyanosis or clubbing but the circulation in her extremities is poor. She is rather torpid and inactive and has shown no signs of cardiac failure.

CASE 3.-Male, aged 13 years, whose imbecility is definitely Mongolian in type. $\mathrm{He}$ is a medium-grade imbecile in good health. The area of cardiac dulness is not increased towards the right; on the left it extends beyond the nipple line by a finger's breadtb. A double murmur is present at the base and is heard better on the left side. There is a loud apical systolic murmur heard also all over the left chest and to a less extent over the right chest also. A systolic thrill is felt at the apex. There is no cyanosis or clubbing and the heart acts well. The boy is a poor walker but is learning to make himself useful.

It is well known that the presence of malformation of the 